Research, part of a Special Feature on Canada and Transboundary Fisheries Management in Changing Oceans: Taking Stock. Future Scenarios

\title{
Challenges to transboundary fisheries management in North America under climate change
}

\author{
Juliano Palacios-Abrantes $^{1}, \underline{U}_{\text {. Rashid Sumaila }}^{2,3}$ and William W. L. Cheung ${ }^{1}$
}

\begin{abstract}
Climate change is shifting the distribution of fish stocks that straddle between exclusive economic zones (EEZ), challenging transboundary fisheries management. Here, we examine the projected sharing of jointly managed transboundary fish stocks between Canada and the United States. We hypothesize that ocean warming will alter the sharing of fish stocks between the two countries, and that such changes will intensify under a high carbon emission scenario. We look at the specific cases of the International Pacific Halibut Commission that manages Pacific halibut (Hippoglossus stenolepis) and a resource sharing arrangement in the Gulf of Maine for cod (Gadus morhua), haddock (Melanogrammus aeglefinus), and yellowtail flounder (Limanda ferruginea) to discuss the management consequences of shifts in transboundary stocks. We rely on multiple Earth system models' simulations and species distribution models to estimate the change in catch potential and stock share ratio of each transboundary stock in the 21 st century under two climate change scenarios. Results show that, even under a low emission scenario, most transboundary fish stocks sharing ratios, i.e., the proportion of the total catch of a fish stock taken by a given country, will change by 2050 relative to present. The overall reduction in catch potential, in addition to the changes in stock-share will further exacerbate trade-offs between changes in species catch potential. Such trade-offs in the Atlantic and Pacific regions will be amplified if a high emission scenario is followed, relative to a low carbon emission scenario. Based on the simulation results, we examine possible solution options to reduce climate risks on transboundary fish stocks and fisheries.
\end{abstract}

Key Words: climate change; joint fisheries management; species distribution shift; transboundary fisheries management

\section{INTRODUCTION}

In 1982, the United Nations Law of the Sea Convention (UNCLOS) formalized the concept of exclusive economic zones (EEZs) creating what we know today as shared stocks (United Nations 1986), i.e., stocks that migrate between countries' EEZs (known as transboundary stocks) or between EEZs and the high seas (also called straddling stocks; Song et al. 2017a). Today, an estimated 347 (Teh and Sumaila 2015) to 1500 (Caddy 1997) fish stocks cross national borders, some of them jointly managed by two or more countries. These stocks are responsible for almost $50 \%$ of these countries total fish catches (Teh and Sumaila 2015). Under Article 63, UNCLOS incentivizes actions to cooperate on the management of shared stocks (United Nations 1986) because often management success depends on effective cooperation between parties (Miller and Munro 2004, Sumaila 2013). Since the definition of shared stocks, game theory has been one of the most common approaches used to analyze the management of these types of stocks. However, shared stocks' management can be convoluted because of the participation of several fishing "players," different countries, and sometimes jurisdictions within a country, the migration patterns of the stock, and their abundance fluctuation within space and time (Miller and Munro 2004, Engler 2020). In addition, international treaties might not be prepared to address the effects that climate change will bring to shared fish stocks (Engler 2020, Koubrak and VanderZwaag 2020, Oremus et al. 2020).

The ocean is getting warmer (IPCC 2019), less oxygenated (Schmidtko et al. 2017), and increasing in acidity (Ross et al. 2011, IPCC 2019). To cope with these changes in ocean biophysic properties, marine species, including shared fish stocks, have been shifting their distribution toward the poles and/or deeper waters
(Poloczanska et al. 2016). As climate change reshapes the ocean's environment worldwide (Gattuso et al. 2015), shared fisheries' delicate governance is threatened as new migration patterns may arise (Miller et al. 2013, Pinsky et al. 2018), historic distribution and abundances might shift (Cheung et al. 2010), and species' basic natural traits may modify (Pauly and Cheung 2018). Catches of shared stocks like tunas, have significantly increased in some regions such as the subtropical Atlantic and western Pacific Oceans and are projected to continue (Monllor-Hurtado et al. 2017, Erauskin-Extramiana et al. 2019). Multiple shared species in North America have been observed to shift in distribution following changes in optimal conditions such as sockeye salmon (Oncorhynchus nerka; McDaniels et al. 2010), Atlantic cod (Gadus morhua; Pershing et al. 2015), and flounders (Pinsky and Fogarty 2012). Moreover, these shifts are projected to continue toward the end of the 21st century (Cheung 2018). As a result, some countries or management jurisdictions may see more shared fisheries and their catches shifting into their waters while others will stand to lose (Pinsky et al. 2018, Oremus et al. 2020). Nevertheless, management rules for shared stocks, e.g., quota or spatial delimitation, are often determined based on current and/or historic knowledge of the stock's distribution and do not consider future shifts in distributions (Fredston-Hermann et al. 2018).

The shifts in distribution of shared fish stocks will impact the economics of their fisheries (Pinsky and Fogarty 2012, Sumaila 2019, Sumaila et al. 2020), and create international disputes between countries (Miller and Munro 2004, Spijkers and Boonstra 2017, Pinsky et al. 2018). Canada and the U.S. share important transboundary stocks of salmon (Oncorhynchus spp.), Pacific halibut (Hippoglossus stenolepis), and Atlantic cod offering a unique lens to understand the extent to which climate-

${ }^{1}$ Changing Ocean Research Unit, Institute for the Oceans and Fisheries, The University of British Columbia, Vancouver, Canada, ${ }^{2}$ Fisheries Economics Research Unit, Institute for the Oceans and Fisheries, The University of British Columbia, Vancouver, Canada, ${ }^{3}$ School of Public Policy and Global Affairs, The University of British Columbia, Vancouver, British Columbia, Canada 
induced distributional shifts will challenge the future sustainability of transboundary fisheries. These countries have a long history of fisheries cooperation participating in diverse, jointly managed, commercial transboundary stocks through various fisheries management organizations (NOAA 2018). Furthermore, climaterelated fluctuations in stocks' distribution have historically created disputes between Canada and the U.S., increasing international conflict and threatening the health of diverse transboundary stocks (Miller and Munro 2004, CIA 2012).

It is expected that climate induced shifts in stocks' distribution will affect the rules in place that keep international treaties alive. Therefore, our main objective is to assess the level of exposure that bilateral transboundary fisheries treaties between Canada and the U.S. have to climate change through shifts in stock distributions. Specifically, we rely on a species distribution model and scenario planning to project the changes in the distribution of selected fish stocks jointly managed by Canada and the United States focusing on two case studies (the International Pacific Halibut Commission and a fisheries arrangement for the Gulf of Maine). Finally, we explore similar situations around the world and identify opportunities to improve the adaptability of transboundary stocks management to climate change in North America. Despite an overall expectation of species following a poleward shift, important geographic constraints (e.g., the Gulf of Alaska representing a latitudinal block; Kleisner et al. 2016), geopolitical features (e.g., the localization of Alaska in reference to Canada and the contiguous states), and management rules (e.g., quota allocations and spatial management rules) may play an important role in the redistribution of benefits. Understanding these stocks shifts will shed a light on future conditions and inform decision makers on the paths to follow under a changing climate.

\section{METHODS}

\section{Study area and fisheries}

We used the International Pacific Halibut Commission (IPHC) and the Gulf of Maine arrangement (hereafter referred as GoMA) as case studies to discuss the implications that climate change could have in the management of transboundary stocks. For the IPHC, we used the most updated spatial regulatory data along its 12 regulatory areas (IPHC and Gustafson 2017, IPHC 2019). For this specific case, we considered Alaska as a separate entity, the U.S. contiguous states as a second one (Washington, Oregon, and California), and lastly British Columbia (Canada). For the GoMA we used the Northwest Atlantic Fisheries Organization's (NAFO, https://www.nafo.int/Science/) divisions 5Y, 5Ze, and 4X within latitudes $46^{\circ} \mathrm{N}$ and $41.5^{\circ} \mathrm{S}$, and longitudes $-72^{\circ} \mathrm{W}$ and $-64^{\circ} \mathrm{E}$ (Fig. 1). It is worth mentioning that although NAFO's divisional zones were used in this study for domestic management, NAFO does not manage fisheries within the EEZs of Canada and the United States. Fisheries data was gathered from the "Sea Around Us" from 1951 to 2014 (Zeller et al. 2016).

\section{The International Pacific Halibut Commission}

The IPHC was established by Canada and the United States to oversee the management of Pacific halibut (IPHC 2014). There are 12 regulatory areas from which $3 \mathrm{AB}$ holds $51.2 \%$ of the stock, followed by regions $2 \mathrm{ABC}$ and $4 \mathrm{ACDE}$ with $23.1 \%$ and $20.4 \%$, respectively, and lastly region $4 \mathrm{~B}$ with only $5.2 \%$ of the stock distribution (IPHC and Gustafson 2018). In terms of management, the IPHC implements a total allowable catch (TAC) based on a yearly sampling of the Convention area in addition to a series of regulations to control fishing effort (IPHC and Gustafson 2018). The TAC is divided between recreational, subsistence, and commercial fishery, with a portion set aside for bycatch of other fisheries (IPHC 2019). The commercial fishing season starts in March ending around November with restrictions allowing only set line gear with J-type hooks targeting individuals over $81.3 \mathrm{~cm}$ of total length (IPHC 2019).

Fig. 1. Map of North America with the regulatory areas of the International Pacific Halibut Commission (IPHC) and the Northwest Atlantic Fisheries Organization (NAFO) subregion related to the Gulf of Maine agreement. "CA" = closed area.

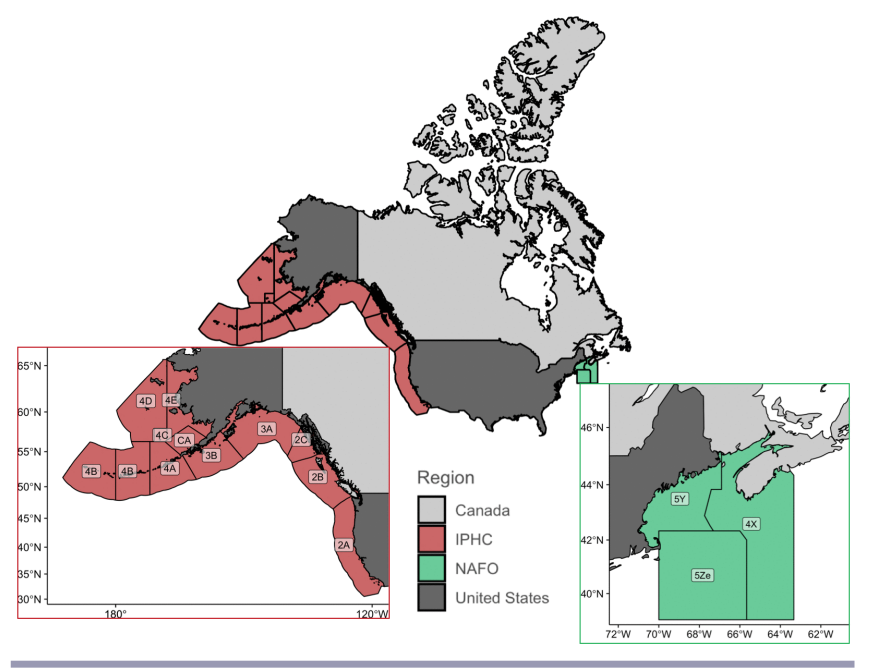

The Gulf of Maine arrangement

Since 2003 Canada and the U.S. have used "resource sharing understanding" to inform the management of Eastern George Bank's Atlantic cod and haddock (Melanogrammus aeglefinus) and yellowtail flounder (Limanda ferruginea; Pudden and VanderZwaag 2007, TRAC 2016, Song et al. 2017b). From 2010 onward, the GoMA suggests catch-limits based on a weighted method whereby $10 \%$ represents the stocks' historical distribution (from 1967 to 1994) and 90\% current distributions produced by quarterly surveys and catch (TRAC 2016). Since its introduction, the average quota allocation for each species proposed by the GoMA has been Atlantic cod 77\% Canada and 23\% U.S., haddock 55\% Canada and $45 \%$ U.S., and yellowtail flounder $34 \%$ Canada and 66\% U.S. (Table 1; TRAC 2015a, $b, c$, TRAC 2018a, $b, c$, Clark and Trinko-Lake 2019). However, because this is an unofficial agreement, Canada and the U.S. ultimately take single management decisions (Soboil and Sutinen 2006). In terms of management, the U.S. has a multispecies harvest control with area and season closures, mesh sizes, effort control, and mobile gear vessels that use bottom otter trawl gear (Soboil and Sutinen 2006). In contrast, Canada has a quota system in addition to limitedentry licensing, fleet allocations, and mesh and fish size regulation, among other input controls. Canadian inshore vessels fish cod with longline and gillnet whereas haddock is mainly caught with bottom otter trawl gear (Soboil and Sutinen 2006). 
Table 1. Historical quota for Atlantic cod (Gadus morhua), haddock (Melanogrammus aeglefinus), and yellowtail flounder (Limanda ferruginea) managed under the Gulf of Maine agreement for Canada and the United States. Values represent percentage of total quota that each country had.

\begin{tabular}{|c|c|c|c|c|c|c|}
\hline & \multicolumn{2}{|c|}{ Atlantic cod } & \multicolumn{2}{|c|}{ Haddock } & \multicolumn{2}{|c|}{$\begin{array}{l}\text { Yellowtail } \\
\text { flounder }\end{array}$} \\
\hline & Canada & U.S. & Canada & U.S. & Canada & U.S. \\
\hline Historic Average $^{\dagger}$ & 72 & 28 & 65 & 35 & 27 & 73 \\
\hline $2010^{1}$ & 77 & 23 & 59 & 41 & 40 & 60 \\
\hline $2011^{1}$ & 82 & 18 & 57 & 43 & 44 & 56 \\
\hline $2012^{2}$ & 71 & 29 & 57 & 43 & 51 & 49 \\
\hline $2013^{2}$ & 83 & 17 & 62 & 38 & 57 & 43 \\
\hline $2014^{2}$ & 71 & 29 & 61 & 39 & 18 & 82 \\
\hline $2015^{2}$ & 83 & 17 & 52 & 48 & 30 & 70 \\
\hline $2016^{2}$ & 83 & 17 & 59 & 41 & 24 & 76 \\
\hline $2017^{2}$ & 86 & 14 & 41 & 59 & 31 & 69 \\
\hline $2018^{2,3}$ & 70 & 30 & 61 & 39 & 29 & 71 \\
\hline $2019^{3}$ & 71 & 29 & 50 & 50 & 24 & 76 \\
\hline $2020^{3}$ & 71 & 29 & 46 & 54 & 26 & 74 \\
\hline $\begin{array}{l}\text { Weighted method } \\
\text { Average }^{*}\end{array}$ & 77 & 23 & 55 & 45 & 34 & 66 \\
\hline $\begin{array}{l}\text { Weighted method St. } \\
\text { Dev. }\end{array}$ & 6 & 6 & 7 & 7 & 12 & 12 \\
\hline
\end{tabular}

Average from 2006 to 2009, before the implementation of the weighted method Average from 2010 to 2020 since the implementation of the weighted method standard deviation of the 2010-2020 average

${ }^{1}$ TRAC $(2015 a, b, c){ }^{2}$ TRAC (2018a, b, c), ${ }^{3}$ Lake (2019)

\section{Projecting future species distribution}

We used a dynamic bioclimatic envelope model (DBEM) to project the distribution of species from 2015 to 2100 under two scenarios of climate change (Cheung et al. 2010, 2016a). The DBEM algorithm integrated ecophysiology and habitat suitability with spatial population dynamics of exploited fishes and invertebrates to project shifts in abundance and potential fisheries catches under climate change. The algorithm predicted species distribution based on depth and latitudinal range, habitat preferences, and an index of species association with major habitat types to estimate changes in abundance distribution over a $0.5^{\circ} \times 0.5^{\circ}$ grid of the world ocean. For each grid cell and time step, the model then calculated species carrying capacity according to sea surface temperature, salinity, oxygen content, sea ice extent (for polar species), and bathymetry, as well as the species preferences to these conditions. It then incorporated the intrinsic population growth, settled larvae, and net migration of adults from surrounding cells using an advection-diffusionreaction equation. Finally, the model also simulated the effects of changes in temperature and oxygen content on growth of individuals (Cheung et al. 2013, 2016a). Ultimately, the model simulated spatial and temporal population dynamics, and estimated a proxy of maximum sustainable yield (MSY) by applying fishing at MSY level for each grid cell, hereafter referred as maximum catch potential (MCP).

We projected the DBEM using three Earth system models (ESM): the Geophysical Fluid Dynamics Laboratory Earth system models 2M (GFDL, https://www.gfdl.noaa.gov), the Institute Pierre Simon Laplace climate model 5 (IPSL-CM5, http://cmc. ipsl.fr/international-projects/cmip5/), and the Max Planck Institute for Meteorology Earth system model(MPI, https://www. mpimet.mpg.de/en/science/models). Each model was downscaled to match the DBEM $0.5^{\circ} \times 0.5^{\circ}$ grid using the nearest neighbor method, and in some cases, bilinear interpolation (Cheung et al. 2017). Finally, we used the model outputs for two scenarios of the Intergovernmental Panel on Climate Change (IPCC)Representative Concentration Pathways (RCP) 2.6 and 8.5 representing a low greenhouse gas emission (strong mitigation) and a high greenhouse gas emission (week mitigation) scenario, respectively (IPCC 2014). To estimate model robustness and capture the structural uncertainty build within ESM models, we averaged the DBEM results for all three models $(\mu \pm \sigma)$ and marked regions where at least one ESM disagree in direction with the rest.

\section{Estimation of maximum catch potential change}

For estimating the percentage change of $\mathrm{MCP}$ at the regional scale, we first aggregated the yearly MCP of each species per region $\left(X_{y r}\right)$ and period:

$$
X_{y r}=\sum_{s=1}^{n} M \hat{C} P_{s}
$$

where $y$ is year, $r$ is region, $s$ is grid, $n$ is total number of grids in the region, and MĈP is the MCP of each species. In the case of the GoMA, region was defined as the $0.5^{\circ} \times 0.5^{\circ}$ grid-cell within the specific NAFO regulatory areas. For the IPHC analysis, region was defined as the Commission's regulatory areas (Fig. 1). We then averaged the values in three time periods $(t)$ to reduce temporal model sensitivity. Thus, we computed the regional percentage change in $\mathrm{MCP}\left(\triangle M C P_{r}\right)$ as follows:

$$
\Delta M C P_{r}=-\left(1-\frac{X_{t}}{X_{t 0}}\right) * 100
$$

Where $X_{t}$ is the future averaged MCP for each of the two time periods analyzed in this study and $X_{t 0}$ is the present averaged MCP ( $\mu$ 2005-2014). Note that in cases where $X_{t 0}=0$ and $X_{t}>0$, then $\left(\triangle M C P_{r}\right)=100 \%$, consequently, the opposite case would give a $-100 \%$ result. This way, Equation 2 shows the percentage change in MCP by mid-21st century when $X_{t}=\mu$ 2041-2060, and end of the 21st century when $X_{t}=\mu 2080-2099$, relative to today $\left(X t_{0}\right)$. The rationale between choosing these time periods was to provide a relative short-term projection (midcentury) that would be more policy-relevant but also show the long-term trend (end of century).

In addition, we borrowed the concept of "threat point" from game theory defined as the minimum payoff that a player is willing to receive in order to cooperate with other players (see Sumaila et al. 2020). Thus, we estimated the change in the $\triangle M C P_{r}$ (threat point) that each country (players) would have for each species (hereafter referred as stock-share ratio), for both the IPHC and the GoMA. The stock-share ratio can be seen as the proportion of the stock's distribution within the study area that each country has. For this, we first modified Equation 1, to estimate the aggregated yearly mean MCP of each species per region. We then averaged the results by the same previously motioned periods (present, mid-, and end of the 21 st century). Next, for each species we estimated the stock-share ratio $\left(\alpha_{s}\right)$ that each region had during each time period:

$$
\alpha_{t s}=\frac{\theta_{r t}}{\delta_{t s}}
$$

Where $\theta_{r t}$ is the species' aggregated MĈP of each region at time period $t$, and $\delta_{\text {ts }}$ is the species' aggregated MĉP of the whole species' distribution within the study area at the same time period. 
Finally, we estimated the percentage change in stock-share ratio substituting $X_{t 0}$ and $X_{t}$ by $\alpha_{t 0}$ and $\alpha_{t}$, respectively in Equation 2 . The process was carried out for each ESM and results presented as average \pm standard deviation $(\mu \pm \sigma)$. All of the analysis was done in the statistical software $R$ version 3.5.2 (2018-12-20) with the associated packages, data.table (Dowle et al. 2019), ggrepel (Slowikowski et al. 2019), gridExtra (Auguie 2017), knirt (Xie 2020), RColorBrewer (Neuwirth 2014), sf (Pebesma et al. 2018), and tidyverse (Wickham 2017). All code is available at http://www. github.com/jepa/OC Transboundary.

\section{RESULTS}

Projected change to species managed by the IPHC

At least one third of the IPHC regulatory areas will see a reduction in MCP of Pacific halibut by 2050 relative to current MCP, regardless of the climate change scenario (Fig. 2). It is likely that the stock shift from the U.S. contiguous states toward Canada will offset the shift from Canada toward northern regions, resulting in undetectable changes in Canadian area 2B and Alaskan 2C under both climate change scenarios. The potential movement of halibut westward will increase the MCP of regulatory areas $3 \mathrm{~B}$ (under a low emission scenario) and $4 \mathrm{ABCE}$ along the Aleutian Islands and Bering Sea. Regions 4DE, the most poleward regulatory areas of the IPHC, are expected to gain MCP by mid- (Fig. 2) and end of the century (Fig. A1.1) under a high emission scenario because of the expansion of halibut suitable habitat as sea ice retreats (Fig. A2.1). In contrast, under a low emission scenario, sea ice is expected to stabilize toward mid-21st century, thus providing less "new" suitable habitat for Pacific halibut and resulting in undetectable changes in MCP for the region (Fig. 2B) and decreasing even more toward 2100 (Fig. A1.1).

Fig. 2. Percentage change of maximum catch potential (MCP) for species managed by the International Pacific Halibut Commission for mid-21st century (2041-2060) relative to the present 2005-2014 under a (A) high emission scenario and (B) low emission scenario. Labels marked with "*” represent regions where models do not agree in direction of change.

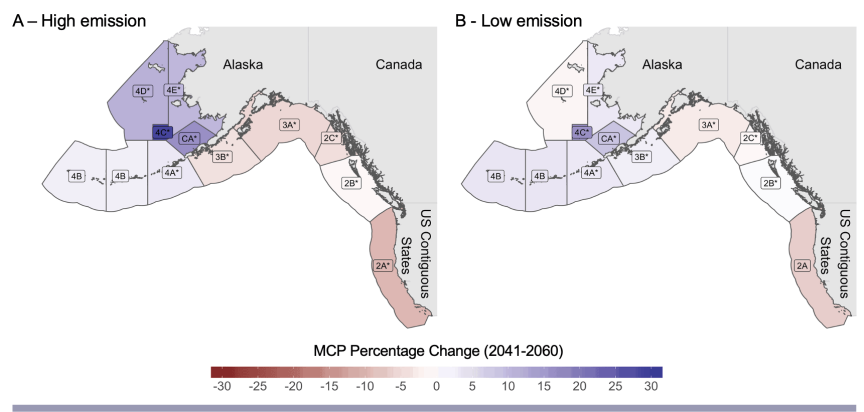

The same poleward trend is expected in the change of Pacific halibut stock-share ratio with the average proportion increasing up to $25 \%$ in some northern regions and decreasing by $10 \%$ in southern regions, relative to the present proportion (Fig. 3). Maintaining emissions to lower levels through 2050 would potentially leave unchanged the stock-share ratio of three regulatory areas (3AC, and 4D) and negatively change regulatory area $2 \mathrm{~A}$. On the other hand, failing to achieve such target will decrease the stock-share ratio in the most productive regulatory areas $(2 \mathrm{AC}, 3 \mathrm{AB})$.

Fig. 3. Percentage change of stock-share ratio for International Pacific Halibut Commission under (A) high emission scenario and (B) low emission scenario for mid-21st century (2041-2060) relative to the present 2005-2014. Values represent the mean of three Earth system models; error bars represent $\pm \mathrm{sd}$.

\section{A-High emission B - Low emission \\ Region $\square$ Alaska $\square$ Canada $\square$ us Contiguous}

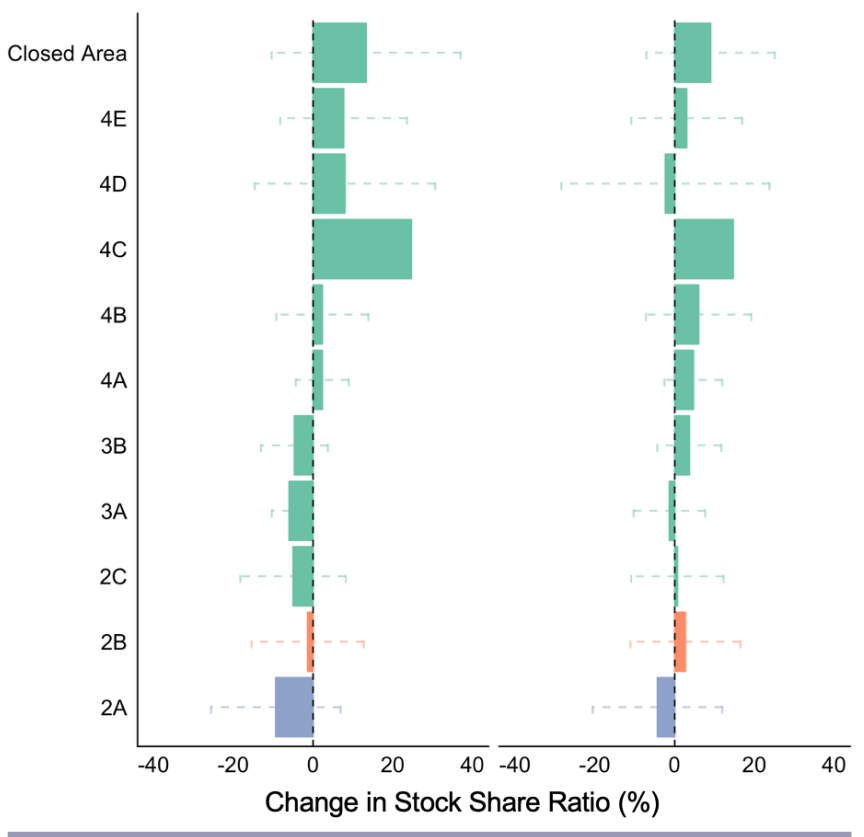

\section{Projected change to species managed under the Gulf of Maine arrangement}

While some regulatory areas of the IPHC will see an incremental increase in Pacific halibut MCP, the results for the Gulf of Maine show an overall decrease in MCP by 2050, regardless of the climate change scenario (Fig. 4) or ESM (Fig. A2.3), intensifying by the end of the century (Fig. A1.2). For cod and haddock, MCP will decrease within the whole Gulf with no apparent win for any country in reference to the current period (Fig. 4). For yellowtail flounder, despite an overall reduction, some discrete areas are expected to increase with no particular pattern and high uncertainty because ESMs in these regions do not agree in the direction of change (Fig. A2.3). Despite the overall reduction in MCP for all three species in comparison to current values, there is a benefit of achieving a low emission scenario as reductions intensify under the high emission scenario.

Despite the expected decrease in MCP for the region, changes in the stock-share ratio of species within the Gulf of Maine show different outcomes dependent on the climate change scenario and species in question. Following a high emission path will affect mostly Canada's share of yellowtail flounder and, to a lesser degree, haddock, with an increase of cod share. Under the low emission scenario, haddock and cod patterns intensify, while yellowtail flounder's share approaches almost no change (Fig. 5). 
Fig. 4. Percentage change of maximum catch potential (MCP) in the Gulf of Maine under (A) high emission scenario and (B) low emission for midcentury (2041-2060) relative to the present (2005-2014). Values represent the mean of three Earth system models (ESMs). Points represent regions where ESMs do not agree in direction of change

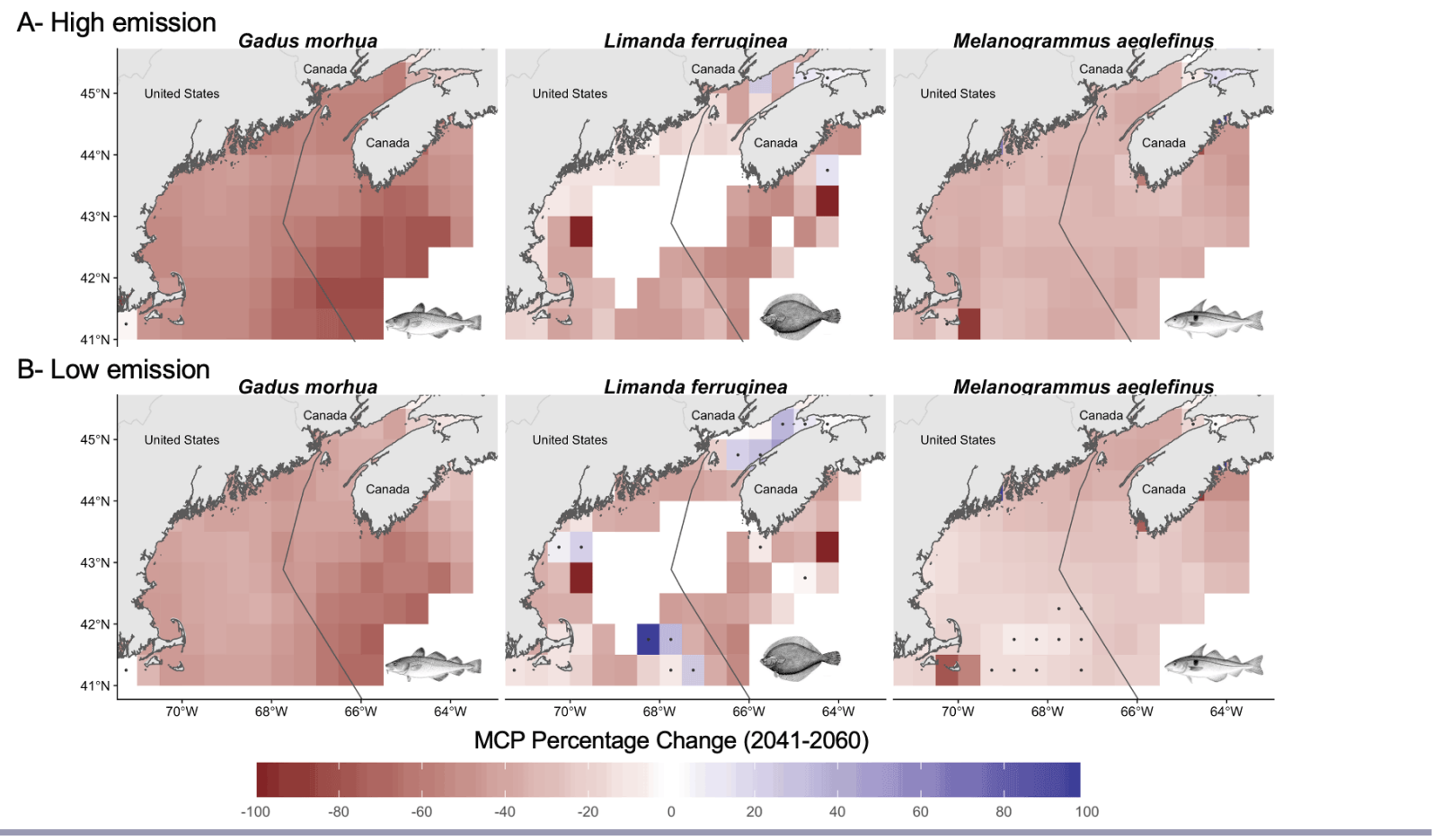

Such pattern is likely the combination of the bathymetry of the Gulf, the warming gradient, and the species distribution.

\section{DISCUSSION}

The results of the present study suggest that climate change will alter the MCP of jointly managed transboundary fish stocks in North America consequently altering Canada's and the U.S.'s species' stock-share ratio, regardless of the climate change scenario. These results are aligned with regional (Morley et al. 2018) projections suggesting that climate change will push marine species toward the poles and deeper water (Pinsky et al. 2013) in search of their ecological niche (Poloczanska et al. 2016). Moreover, IPHC data (https://www.iphc.int/data/time-seriesdatasets) suggest that some of these shifts are already happening. For example, since 2010, the distribution proportion of Pacific halibut has increased from $9 \%$ to $11 \%$ in region $2 \mathrm{~B}$, from $7.5 \%$ to $13 \%$ in region $2 \mathrm{C}$, and from $12.3 \%$ to $13.5 \%$ in region $4 \mathrm{CDE}$. On the other hand, regions $3 \mathrm{~A}$ and $3 \mathrm{~B}$ have seen the largest decreases in the IPHC regulatory areas since 2010 , from $35.3 \%$ to $30.6 \%$ and $20.6 \%$ to $15.9 \%$, respectively. Similarly, in the Gulf of Maine, the projected stock-share gain of yellowtail flounder and haddock by the U.S. (Fig. 5) follows a historical trend where in 2019, Canada's stock-share decreased from $35 \%$ to $32 \%$ and $60 \%$ to $40 \%$ relative to 2010, respectively (Clark and Trinko-Lake 2019).

Geographic barriers (Cheung et al. 2015, Kleisner et al. 2016), local temperature gradients (Pinsky et al. 2013), species interactions and human activities (Serpetti et al. 2017) might change the rate and direction of species shifts. For the IPHC, geographic barriers might induce a westward increase of stockshare in IPHC regions where species can only migrate northward into the Arctic Ocean through the Bering Sea and Bering Strait (Cheung et al. 2015; Fig. 3). In the Gulf of Maine, future projections could be a response to a temperature gradient shift combined with geographic barriers because southern waters are deeper and warming slower than northern waters according to the ESMs (Fig. A2.2). Moreover, Maine has seen its landings of yellowtail flounder increased at the expenses of southern states (Pinsky and Fogarty 2012). This could be influencing the U.S. gain in MCP in the GoMA in relation to Canada as species shift their distribution from lower latitudes naturally reaching the $\mathrm{U}$. S. (lower) region first. As the effects of climate change endure, even with high mitigation, joint plans should prepare to face changes in the stock-share ratio of transboundary stocks along both coasts of North America.

The shifts in the distribution of transboundary stocks can jeopardize management objectives such as conservation measures and gear operation. Fish moving out of fishing grounds and into protected areas could result in a pressure increase to open such areas to fishing. Moreover, overlapping shifting stocks could interfere in gear-limitation management rules of multiple fisheries generating conflicts between fleets (Van Der Voo 2016). The effectiveness of the IPHC-closed area ("CA" in Fig. 1) in terms of protecting juveniles has been historically questioned because trawling for other species is still allowed in the area (Karim et al. 2010, IPHC 2017). In 2015, for example, $97 \%$ of the trawl bycatch in areas 4CDE and the closed area were juveniles (IPHC 2017). 
Fig. 5. Changes in maximum catch potential (MCP) stock-share ratio for Gulf of Maine under (A) high emission scenario and (B) low emission scenario for midcentury (2041-2060) relative to 2005-2014. Values represent the mean of three Earth system models (ESM); error bars represent $\pm \mathrm{sd}$.

$$
\text { A-High emission } \quad \text { B - Low emission }
$$

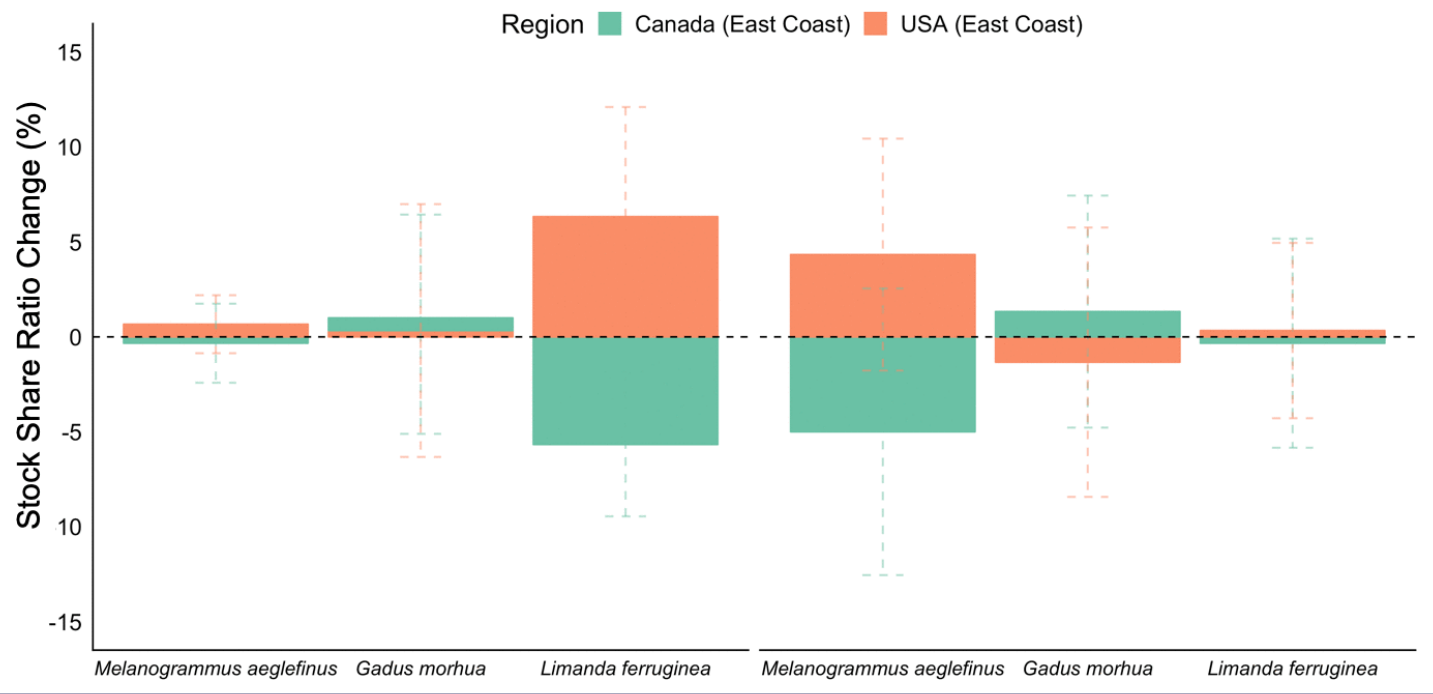

Consequently, the Alaskan trawl fisheries has been closed before reaching annual quota because of the attainment of Pacific halibut bycatch quota limits (Karim et al. 2010). Thus, the commission has been asked to open the closed area for Pacific halibut fishing, under the premise that the expansion of the trawl fishery is likely reducing any conservation goal for juvenile Pacific halibut (IPHC 2017). Although not assessed in this study, some trawling target species like Pacific cod (Gadus macrocephalus), flathead sole (Hippoglossoides elassodon), and Alaskan plaice (Pleuronectes quadrituberculatus) have already shifted their distributions because of warming waters (Stram and Evans 2009) and some are expected to continue shifting in similar direction than Pacific halibut (Pinsky et al. 2013). The overlap of target species could be addressed by applying ecosystem-based management and dynamic management tools (Hazen et al. 2018) to manage these fisheries and reduce potential loss of sustainable harvest for both the halibut and the trawl fisheries.

Quota allocation ruled by historic distributions will most likely be outdated incentivizing maladaptation (Miller et al. 2013, FAO 2018, Gaines et al. 2018). In Europe, for example, the EU Common Fisheries Policy quota allocation is based on the historic reference period of the 1970s (Harte et al. 2019). However, climate change has shifted the distribution of multiple European commercial stocks (Baudron et al. 2020), outdating the fixed quotas and thus compromising the sustainability of European fisheries (FAO 2018, Baudron et al. 2020). Management regimes that include a dynamic harvest control, e.g., adjusting the quota based on the stocks distribution, have the potential of increasing fish biomass, harvest, and profits under climate change (Gaines et al. 2018). In North America, poleward shifts of Pacific halibut along the coast of Oregon, Washington, and British Columbia have been previously addressed by the IPHC resulting in the adoption of a dynamic quota allocation method (McCaughran and Hoag 1992). By allocating quotas based on yearly surveys along the Convention area, the IPHC should be able to capture shifts in Pacific halibut distribution caused by climate change, reducing the chances of overexploitation of the stock due to these shifts (Miller et al. 2013). Similarly, for the Gulf of Maine, the GoMA's method to estimate quota allocation is weighted based on stocks distribution $(90 \%)$ and historical catch $(10 \%$; TRAC 2016). This process is especially important for cod and haddock because of their distribution variation within the Gulf (Soboil and Sutinen 2006, TRAC 2016). However, since 2010, when the weighted method was implemented, the quota allocation has favored the U.S. over Canada, especially in terms of haddock and yellowtail flounder (Clark and Trinko-Lake 2019). A perpetuation of this trend with no mitigation policy could jeopardize the arrangement as Canada's quota reduction could disincentivize cooperation (Sumaila et al. 2020).

Side payments have been previously used to address changes in species distribution, including cases caused by environmental forcings. In game theory, a side payment is received by a player as a compensation from the other player in a shared resource agreement, with the premise that cooperation will result in a better overall outcome (Bjørndal and Munro 2012, Sumaila 2013). Side payments do not have to be in monetary form and are widely used in transboundary stocks around the world. For example, Norway and Russia have implemented a quota swap strategy for jointly managed stocks of cod, haddock, and capelin (Mallotus villosus) in the Barents Sea (http://www.jointfish.com/eng/THEFISHERIES-COMMISSION/HISTORY.html). Similarly, species' quota swaps are allowed, up to a degree, within regulatory areas of the European Union (Baudron et al. 2020). Specifically, for northern European spring spawning herring (Clupea harengus), Norway, Iceland, Faroe Islands, Russia, and the EU reached an agreement to manage the stock after it collapsed, partially due to 
climate variations (Miller et al. 2013). Among the implemented rules, the agreement established a dynamic quota allocation, allowing members to fish part of their quota within Norway's EEZ, and land the catch in Norwegian ports. In North America, Canada and the U.S. have previous history with the utilization of side payments when in the 1970s Pacific salmon shifted its distribution resulting in large interceptions of Canada's salmon by Alaskan fisheries (Miller et al. 2013, Song et al. 2017b). The conflict was resolved by the implementation of a conservation fund that worked as a side payment for both Canada and the state of Alaska (Miller et al. 2013, Song et al. 2017b). The potential adaptation of side payments in terms of quota swaps or allocating EEZ-fishing rights across the Gulf of Maine EEZs could be a potential solution as stocks shift due to climate change.

Transboundary fisheries management has to be prepared for the uncertainty that comes with a changing world. Future climate change will depend on the path society as a whole will take, and thus we rely on scenario planning to account for the uncertainty built into future decision making (van Vuuren et al. 2011). In our results, the winners and losers of climate change, and the intensity of the change, will be scenario dependent. For instance, stockshare of yellowtail flounder under a high emission scenario will be larger for the U.S. while Canada's gain of cod stock-share will be larger under a low emission scenario (Fig. 5). Applying previously describe strategies, e.g., quota swaps or EEZ-fishing rights, could increase the resilience of treaties by preventing members from leaving the agreement because of a shift in threat points, as happened in the Pacific salmon case (Miller et al. 2013).

Models are attempts to represent reality (in our case a future reality) based on observational data, previously established theory, and future scenarios, and are thus, subjected to different degrees of uncertainty (Payne et al. 2016). An ensemble of models is a way to present a more robust result that accounts for differences in the structural composition of each model (Cheung et al. 2016b). We used three ESMs to project future changes in species maximum catch potential. The levels of uncertainty related to the ESMs differ among case studies. Overall, results for the Gulf of Maine agree with a reduction in MCP of all three species. However, some discrete areas show a positive change for yellowtail flounder by midcentury (Fig. 3), mainly driven by the GFDL model (Fig. A2.3). Potential model artifacts could also be contributing to the results, especially in the northern part of the study area (Bay of Fundy) because most disagreeing grids are covered by land, which could be influencing the results. In contrast, considerable uncertainty exists in the change of MCP along the IPHC Convention area shown by a disagreement between ESMs (Fig. A2.4). Off the coast of British Columbia, increasing temperature trends are consistent among ESMs, however, other processes such as acidification and deoxygenation are still not well understood from British Columbia to the Gulf of Alaska (Talloni-Álvarez et al. 2019). Moreover, considerable uncertainty exists along the Bering Sea (Douglas 2010) and Antarctic Pacific regarding the extent and intensity of future seaice reduction under climate change (Steiner et al. 2015, IPCC 2019). Regarding the DBEM, its structural uncertainty has been previously tested for agreement against commonly used species distribution algorithms such as Maxent (Phillips et al. 2006) and AquaMaps (Ready et al. 2010, Kaschner et al. 2011) resulting in no qualitative differences in trends between algorithms (Cheung et al. 2016a). Finally, it is worth mentioning that future changes to species distributions could be influenced by factors not captured by our model such as interactions between species (Pecl et al. 2017), adaptation of species to environmental changes, and anthropogenic factors (Serpetti et al. 2017). However, these factors are expected to increase the rate of range-shifting of the species making our results conservative (Cheung et al. 2010, Serpetti et al. 2017).

\section{CONCLUSIONS}

Shifts in stocks distribution due to climate change have the potential of creating local extinction of economically important stocks while enhancing fisheries in areas where they were not present before. In this paper, we have explored the potential impacts of climate change in the joint management of selected transboundary stocks managed by Canada and the U.S. We found that, transboundary stocks are likely to shift in the upcoming years changing the proportion of the catch of jointly managed fisheries of Canada and the U.S. Lessons from other countries can provide solutions to such challenges. More specific, side payments, dynamic management, and interchangeable quotas were identified as potential solutions for the North American region. Although not directly addressed in this study, socioeconomic impacts of shifting transboundary stocks could add an extra layer of complexity to the problem. Addressing shifts in stocks distribution sooner rather than later could avert the so called fish wars, improve sustainability of jointly managed stocks, and secure the livelihood of thousands of families that depend on stocks that move freely between national jurisdictions. Finally, preparing for an uncertain future is key to achieve sustainable fisheries.

Responses to this article can be read online at: https://www.ecologyandsociety.org/issues/responses. php/11743

\section{Acknowledgments:}

This is a product of the OceanCanada Partnership funded by the Social Sciences and Humanities Research Council of Canada. The authors would like to thank Ms. Susan Rolston for her support in the production of the manuscript.

\section{Data Availability:}

Raw data produced in this research can be found at https://dataverse. scholarsportal.infoldataverseloceancanada and the code to analyze it at https://github.com/jepalOC Transboundary.

\section{LITERATURE CITED}

Auguie, B. 2017. Package gridExtra; Miscellaneous Functions for "Grid" Graphics R (3.5.0).

Baudron, A. R., T. Brunel, M. A. Blanchet, M. Hidalgo, G. Chust, E. J. Brown, K. M. Kleisner, C. Millar, B. R. MacKenzie, N. Nikolioudakis, J. A. Fernandes, and P. G. Fernandes. 2020. Changing fish distributions challenge the effective management 
of European fisheries. Ecography 43(4):494-505. https://doi. org/10.1111/ecog.04864

Bjørndal, T., and G. Munro. 2012. The economics andmanagement of world fisheries. First edition. Oxford University Press, Oxford, UK. https://doi.org/10.1093/acprof:oso/9780199576753.001.0001

Caddy, J. 1997. Establishing a consultative mechanism or arrangement for managing shared stocks within the jurisdiction of contiguous states. Pages 80-123 in D. A. Hancock, editor. Taking stock defining and managing shared resources. Australian Society for Fish Biology, Darwin, Australia.

Central Intelligence Agency (CIA). 2012. The US-Canadian Dispute Over the Georges Bank. CIA, Washington, D.C., USA.

Cheung, W. W. L. 2018. The future of fishes and fisheries in the changing oceans. Journal of Fish Biology 92(3):790-803. https:// doi.org/10.1111/jfb. 13558

Cheung, W. W. L., R. D. Brodeur, T. A. Okey, and D. Pauly. 2015. Projecting future changes in distributions of pelagic fish species of Northeast Pacific shelf seas. Progress in Oceanography 130 (C):19-31. https://doi.org/10.1016/j.pocean.2014.09.003

Cheung, W. W. L., T. L. Frölicher, R. G. Asch, M. C. Jones, M. L. Pinsky, G. Reygondeau, K. B. Rodgers, R. R. Rykaczewski, J. L. Sarmiento, C. Stock, and J. R. Watson. 2016b. Building confidence in projections of the responses of living marine resources to climate change. ICES Journal of Marine Science 73 (5):1283-1296. https://doi.org/10.1093/icesjms/fsv250

Cheung, W. W. L., M. C. Jones, V. W. Y. Lam, D. D Miller, Y. Ota, L. Teh, and U. R. Sumaila. 2017. Transform high seas management to build climate resilience in marine seafood supply. Fish and Fisheries 18(2):254-263. https://doi.org/10.1111/ faf.12177

Cheung, W. W. L., M. C. Jones, G. Reygondeau, C. A. Stock, V. W. Y. Lam, and T. L. Frölicher. 2016a. Structural uncertainty in projecting global fisheries catches under climate change. Ecological Modelling 325:57-66. https://doi.org/10.1016/j. ecolmodel.2015.12.018

Cheung, W. W. L., V. W. Lam, J. L. Sarmiento, K. Kearney, R. Watson, D. Zeller, and D. Pauly. 2010. Large-scale redistribution of maximum fisheries catch potential in the global ocean under climate change. Global Change Biology 16(1):24-35. https://doi. org/10.1111/j.1365-2486.2009.01995.X

Cheung, W. W. L., R. Watson, and D. Pauly. 2013. Signature of ocean warming in global fisheries catch. Nature 497:365-368. https://doi.org/10.1038/nature12156

Clark, K. J., and T. Trinko-Lake. 2019. Proceedings of the 2019 Transboundary Resources Assessment Committee for Eastern Georges Bank cod and haddock and Georges Bank yellowtail flounder. TRAC Proceed Ser. 2019/001.

Douglas, D. C. 2010. Arctic Sea ice decline: projected changes in timing and extent of sea ice in the Bering and Chukchi Seas. U.S. Geological Survey, Reston, Virginia, USA. https://doi. org/10.3133/ofr20101176

Dowle, M., A. Srinivasan, J. Gorecki, M. Chirico, P. Stetsenko, T. Short, S. Lianoglou, E. Antonyan, M. Bonsch, H. Parsonage, and S. Ritchie. 2019. Package data.table: Extension of 'data.frame' $R$ version 1.13.0.

Engler, C. 2020. Transboundary fisheries, climate change, and the ecosystem approach: taking stock of the international law and policy seascape. Ecology and Society 25(4):43. https://doi. org/10.5751/ES-11988-250443"

Erauskin-Extramiana, M., H. Arrizabalaga, A. J. Hobday, A. Cabré, L. Ibaibarriaga, I. Arregui, H. Murua, and G. Chust. 2019. Large-scale distribution of tuna species in a warming ocean. Global Change Biology 25(6):2043-2060. https://doi.org/10.1111/ gcb. 14630

Fredston-Hermann, A., S. D. Gaines, and B. S. Halpern. 2018. Biogeographic constraints to marine conservation in a changing climate. Annals of the New York Academy of Sciences 1429 (1):5-17. https://doi.org/10.1111/nyas. 13597

Food and Agriculture Organization of the United Nations (FAO). 2018. Impacts of climate change on fisheries and aquaculture: synthesis of current knowledge, adaptation and mitigation options. FAO, Rome, Italy.

Gaines, S. D., C. Costello, B. Owashi, T. Mangin, J. Bone, J. G. Molinos, M. Burden, H. Dennis, B. S. Halpern, C. V. Kappel, K. M. Kleisner, and D. Ovando. 2018. Improved fisheries management could offset many negative effects of climate change. Science Advances 4(8):eaao1378. https://doi.org/10.1126/sciadv. $\underline{\text { aao } 1378}$

Gattuso, J. P., A. Magnan, R. Billé, W. W. L. Cheung, E. L. Howes, F. Joos, D. Allemand, L. Bopp, S. R. Cooley, C. M. Eakin, O. Hoegh-Guldberg, R. P. Kelly, H. O. Pörtner, A. D. Rogers, J. M. Baxter, D. Laffoley, D. Osborn, A. Rankovic, J. Rochette, U. R. Sumaila, S. Treyer, and C. Turley. 2015. Contrasting futures for ocean and society from different anthropogenic $\mathrm{CO}_{2}$ emissions scenarios. Science 349(6243):aac4722. https://doi.org/10.1126/ science.aac4722

Harte, M., R. Tiller, G. Kailis, and M. Burden. 2019. Countering a climate of instability: the future of relative stability under the Common Fisheries Policy. ICES Journal of Marine Science 76 (7):1951-1958. https://doi.org/10.1093/icesjms/fsz109

Hazen, E. L., K. L. Scales, S. M. Maxwell, D. K. Briscoe, H. Welch, S. J. Bograd, H. Bailey, S. R. Benson, T. Eguchi, H. Dewar, S. Kohin, D. P. Costa, L. B. Crowder, and R. L. Lewison. 2018. A dynamic ocean management tool to reduce bycatch and support sustainable fisheries. Science Advances 4(5):eaar3001. https://doi. org/10.1126/sciadv.aar3001

Intergovernmental Panel on Climate Change (IPCC). 2014. Climate change 2014: impacts, adaptation and vulnerability. Part A: Global and Sectoral Aspects. Working Group II Contribution to the IPCC Fifth Assessment Report. C. B. Field, V. R. Barros, D. J. Dokken, K. J. Mach, M. D. Mastrandrea, T. E. Bilir, M. Chatterjee, K. L. Ebi, Y. O. Estrada, R. C. Genova, B. Girma, E. S. Kissel, A. N. Levy, S. MacCracken, P. R. Mastrandrea, and L. L. White, editors. Cambridge University Press, Cambridge, UK. https://doi.org/10.1017/CBO9781107415379

Intergovernmental Panel on Climate Change (IPCC). 2019. IPCC special report on the ocean and cryosphere in a changing climate. H. O. Pörtner, D. C. Roberts, V. Masson-Delmotte, P. Zhai, M. 
Tignor, E. Poloczanska, K. Mintenbeck, A. Alegría, M. Nicolai, A. Okem, J. Petzold, B. Rama, and N. M. Weyer, editors. In press.

International Pacific Halibut Commission (IPHC). 2014. The Pacific halibut: biology, fishery, and management. IPHC, Seattle, Washington, USA.

International Pacific Halibut Commission (IPHC). 2017. IPHC closed area (Section 10). IPHC, Seattle, Washington, USA.

International Pacific Halibut Commission (IPHC). 2019. Pacific halibut fishery regulations. IPHC, Seattle, Washington, USA.

International Pacific Halibut Commission (IPHC), and $\mathrm{K}$. Gustafson. 2017. IPHC annual report 2016. IPHC, Seattle, Washington, USA.

International Pacific Halibut Commission (IPHC), and $\mathrm{K}$. Gustafson. 2018. IPHC annual report 2018. IPHC, Seattle, Washington, USA.

Karim, T., A. Keizar, S. Busch, J. Dicosimo, J. Gasper, J. Mondragon, M. Culver, and G. Williams. 2010. Report of the 2010 halibut bycatch work group. International Pacific Halibut Commission, Seattle, Washington, USA.

Kaschner, K., D. P. Tittensor, J. Ready, T. Gerrodette, and B. Worm. 2011. Current and future patterns of global marine mammal biodiversity. PLoS ONE 6(5):e19653. https://doi. org/10.1371/journal.pone.0019653

Kleisner, K. M., M. J. Fogarty, S. McGee, A. Barnett, P. Fratantoni, J. Greene, J. A. Hare, S. M. Lucey, C. McGuire, J. Odell, V. S. Saba, L. Smith, K. J. Weaver, and M. L. Pinsky. 2016. The effects of sub-regional climate velocity on the distribution and spatial extent of marine species assemblages. PLOS ONE 11 (2):e0149220. https://doi.org/10.1371/journal.pone.0149220

Koubrak, O., and D. L. VanderZwaag. 2020. Are transboundary fisheries management arrangements in the Northwest Atlantic and North Pacific seaworthy in a changing ocean? Ecology and Society 25(4):42. https://doi.org/10.5751/ES-11835-250442

McCaughran, D. A., and S. H. Hoag. 1992. The 1979 Protocol to the Convention and Related Legislation. Technical Report No.26. International Pacific Halibut Commission, Seattle, Washington, D.C., USA. [online] URL: https://iphc.int/uploads/pdf/tr/ IPHC-1992-TR026.pdf

McDaniels, T., S. Wilmot, M. Healey, and S. Hinch. 2010. Vulnerability of Fraser River sockeye salmon to climate change: a life cycle perspective using expert judgments. Journal of Environmental Management 91(12):2771-2780. https://doi. org/10.1016/j.jenvman.2010.08.004

Miller, K. A., and G. R. Munro. 2004. Climate and cooperation: a new perspective on the management of shared fish stocks. Marine Resource Economics 19:367-393. https://doi.org/10.1086/ mre.19.3.42629440

Miller, K. A., G. R. Munro, U. R. Sumaila, and W. W. L. Cheung. 2013. Governing marine fisheries in a changing climate: a gametheoretic perspective. Canadian Journal of Agricultural Economics/Revue canadienne d'agroeconomie 61(2):309-334. https://doi.org/10.1111/cjag.12011
Monllor-Hurtado, A., M. G. Pennino, and J. L. Sanchez-Lizaso. 2017. Shift in tuna catches due to ocean warming. PLoS ONE 12 (6):e0178196. https://doi.org/10.1371/journal.pone.0178196

Morley, J. W., R. L. Selden, R. J. Latour, T. L. Frölicher, R. J. Seagraves, and M. L. Pinsky. 2018. Projecting shifts in thermal habitat for 686 species on the North American continental shelf. PLoS ONE 13(5):e0196127. https://doi.org/10.1371/journal. pone. 0196127

National Oceanic and Atmospheric Administration (NOAA). 2018. International agreements concerning living marine resources of interest to NOAA fisheries. NOAA, Office of International Affairs, Seafood Inspection, Silver Spring, Maryland, USA.

Neuwirth, E. 2014. ColorBrewer Palettes. $R$ package RColor Brewer version 1.1-2.

Oremus, K. L., J. Bone, C. Costello, J. G. Molinos, A. Lee, T. Mangin, and J. Salzman. 2020. Governance challenges for tropical nations losing fish species due to climate change. Nature Sustainability 3:277-280. https://doi.org/10.1038/s41893-020-0476$\mathrm{y}$

Pauly, D., and W. W. L. Cheung. 2018. Sound physiological knowledge and principles in modeling shrinking of fishes under climate change. Global Change Biology 24(1):e15-e26. https://doi. org $/ 10.1111 /$ gcb. 13831

Payne, M. R., M. Barange, W. W. L. Cheung, B. R. MacKenzie, H. P. Batchelder, X. Cormon, T. D. Eddy, J. A. Fernandes, A. B. Hollowed, M. C. Jones, J. S. Link, P. Neubauer, I. Ortiz, A. M. Queirós, and J. R. Paula. 2016. Uncertainties in projecting climate-change impacts in marine ecosystems. ICES Journal of Marine Science 73(5):1272-1282. https://doi.org/10.1093/icesjms/ $\underline{\text { fsv231 }}$

Pebesma, E., R. Bivand, E. Racine, M. Sumner, I. Cook, T. Keitt, R. Lovelace, H. Wickham, J. Ooms, and K. Müller. 2018. Package sf: Simple Features for $R$. $\mathrm{R}(\geq=3.3 .0)$.

Pecl, G. T., M. B. Araújo, J. D. Bell, J. Blanchard, T. C. Bonebrake, I.-C. Chen, T. D. Clark, R. K. Colwell, F. Danielsen, B. Evengård, L. Falconi, S. Ferrier, S. Frusher, R. A. Garcia, R. B. Griffis, A. J. Hobday, C. Janion-Scheepers, M. A. Jarzyna, S. Jennings, J. Lenoir, H. I. Linnetved, V. Y. Martin, P. C. McCormack, J. McDonald, N. J. Mitchell, T. Mustonen, J. M. Pandolfi, N. Pettorelli, E. Popova, S. A. Robinson, B. R. Scheffers, J. D. Shaw, C. J. B. Sorte, J. M. Strugnell, J. M. Sunday, M.-N. Tuanmu, A. Vergés, C. Villanueva, T. Wernberg, E. Wapstra, and S. E. Williams. 2017. Biodiversity redistribution under climate change: impacts on ecosystems and human well-being. Science 355(6332): eaai9214. https://doi.org/10.1126/science.aai9214

Pershing, A. J., M. A. Alexander, C. M. Hernandez, L. A. Kerr, A. Le Bris, K. E. Mills, J. A. Nye, N. R. Record, H. A. Scannell, J. D. Scott, G. D. Sherwood, and A. C. Thomas. 2015. Slow adaptation in the face of rapid warming leads to collapse of the Gulf of Maine cod fishery. Science 350(6262):809-812. https:// doi.org/10.1126/science.aac9819

Phillips, S. J., R. P. Anderson, and R. E. Schapire. 2006. Maximum entropy modeling of species geographic distributions. Ecological Modelling 190(3-4):231-259. https://doi.org/10.1016/j. ecolmodel.2005.03.026 
Pinsky, M. L., and M. Fogarty. 2012. Lagged social-ecological responses to climate and range shifts in fisheries. Climatic Change 115:883-891. https://doi.org/10.1007/s10584-012-0599-X

Pinsky, M. L., G. Reygondeau, R. Caddell, J. Palacios-Abrantes, J. Spijkers, and W. W. L. Cheung. 2018. Preparing ocean governance for species on the move. Science 360(6394):1189-1191. https://doi.org/10.1126/science.aat2360

Pinsky, M. L., B. Worm, M. J. Fogarty, J. L. Sarmiento, and S. A. Levin. 2013. Marine taxa track local climate velocities. Science 341(6151):1239-1242. https://doi.org/10.1126/science.1239352

Poloczanska, E. S., M. T. Burrows, C. J. Brown, J. García Molinos, B. S. Halpern, O. Hoegh-Guldberg, C. V. Kappel, P. J. Moore, A. J. Richardson, D. S. Schoeman, and W. J. Sydeman. 2016. Responses of marine organisms to climate change across oceans. Frontiers in Marine Science 3(28):515-21. https://doi.org/10.3389/ fmars.2016.00062

Pudden, E. J., and D. L. VanderZwaag. 2007. Canada-USA bilateral fisheries management in the Gulf of Maine: under the radar screen. Review of European, Comparative and International Environmental Law 16(1):36-44. https://doi.org/10.1111/ j.1467-9388.2007.00543.x

Ready, J., K. Kaschner, A. B. South, P. D. Eastwood, T. Rees, J. Rius, E. Agbayani, S. Kullander, and R. Froese. 2010. Predicting the distributions of marine organisms at the global scale. Ecological Modelling 221:467-478. https://doi.org/10.1016/j. ecolmodel.2009.10.025

Ross, P. M., L. Parker, W. A. O'Connor, and E. A. Bailey. 2011. The impact of ocean acidification on reproduction, early development and settlement of marine organisms. Water 3 (4):1005-1030. https://doi.org/10.3390/w3041005

Schmidtko, S., L. Stramma, and M. Visbeck. 2017. Decline in global oceanic oxygen content during the past five decades. Nature 542:335-339. https://doi.org/10.1038/nature21399

Serpetti, N., A. R. Baudron, M. T. Burrows, B. L. Payne, P. Helaouët, P. G. Fernandes, and J. J. Heymans. 2017. Impact of ocean warming on sustainable fisheries management informs the ecosystem approach to fisheries. Scientific Reports 7:13438. https://doi.org/10.1038/s41598-017-13220-7

Slowikowski, K., A. Schep, S. Hughes, S. Lukauskas, J.-O. Irisson, Z. N. Kamvar, T. Ryan, D. Christophe, Y. Hiroaki, and P. Gramme. 2019. Package; 'ggrepel' Automatically position nonoverlapping text labels with 'ggplot2' $R(>=3.0 .0)$ :GPL-3.

Soboil, M. L., and J. G. Sutinen. 2006. Empirical analysis and transboundary management for Georges Bank multispecies fishery. Canadian Journal of Fisheries and Aquatic Sciences 63 (4):903-916. https://doi.org/10.1139/f05-269

Song, A. M., J. Scholtens, J. Stephen, M. Bavinck, and R. Chuenpagdee. 2017a. Transboundary research in fisheries. Marine Policy 76:8-18. https://doi.org/10.1016/j.marpol.2016.10.023

Song, A. M., O. Temby, G. Krantzberg, and G. M. Hickey. 2017 b. Institutional features of US-Canadian transboundary fisheries governance. Pages 156-179 in O. Temby and P. J. Stoett, editors. Towards continental environmental policy. State University of New York Press, Albany, New York, USA.
Spijkers, J., and W. J. Boonstra. 2017. Environmental change and social conflict: the northeast Atlantic mackerel dispute. Regional Environmental Change 17:1835-1851. https://doi.org/10.1007/ s10113-017-1150-4

Steiner, N., K. Azetsu-Scott, J. Hamilton, K. Hedges, X. Hu, M. Y. Janjua, D. Lavoie, J. Loder, H. Melling, A. Merzouk, W. Perrie, I. Peterson, M. Scarratt, T. Sou, and R. Tallmann. 2015. Observed trends and climate projections affecting marine ecosystems in the Canadian Arctic. Environmental Reviews 23(2):191-239. https:// doi.org/10.1139/er-2014-0066

Stram, D. L., and D. C. K. Evans. 2009. Fishery management responses to climate change in the north pacific. ICES Journal of Marine Science 66(7):1633-1639. https://doi.org/10.1093/icesjms/ $\underline{\text { fsp138 }}$

Sumaila, U. R. 2013. Game theory and fisheries. First edition. Routledge, London, UK. https://doi.org/10.4324/9780203083765

Sumaila, U. R. 2019. Climate change: impact on marine ecosystems and world fisheries. Pages 218-222 in P. Ferranti, E. M. Berry, and J. R. Anderson, editors. Encyclopedia of food security and sustainability. Elsevier, Amsterdam, The Netherlands. https://doi.org/10.1016/B978-0-08-100596-5.22009$\underline{\mathrm{X}}$

Sumaila, U. R., J. Palacios-Abrantes, and W. W. L. Cheung. 2020. Climate change, shifting threat points, and the management of transboundary fish stocks. Ecology and Society 25(4):40. https:// doi.org/10.5751/ES-11660-250440

Talloni-Álvarez, N. E., U. R. Sumaila, P. Le Billon, and W. W. L. Cheung. 2019. Climate change impact on Canada's Pacific marine ecosystem: the current state of knowledge. Marine Policy 104:163-176. https://doi.org/10.1016/j.marpol.2019.02.035

Teh, L. S. L., and U. R. Sumaila. 2015. Trends in global shared fisheries. Marine Ecology Progress Series 530:243-254. https://doi. org/10.3354/meps 11049

Transboundary Resources Assessment Committee (TRAC). 2015a. Eastern Georges Bank cod. TRAC Status Report 2015/01. National Oceanic and Atmospheric Administration, Silver Spring, Maryland, USA.

Transboundary Resources Assessment Committee (TRAC). 2015b. Eastern Georges Bank haddock. TRAC Status Report 2015/02. National Oceanic and Atmospheric Administration, Silver Spring, Maryland, USA.

Transboundary Resources Assessment Committee (TRAC). 2015c. Georges Bank yellowtail flounder. TRAC Status Report 2015/03. National Oceanic and Atmospheric Administration, Silver Spring, Maryland, USA.

Transboundary Resources Assessment Committee (TRAC). 2016. Proceedings of the Transboundary Resources Assessment Committee for Eastern Georges Bank Cod and Haddock, and Georges Bank Yellowtail Flounder. Fisheries and Oceans Canada, Ottawa Ontario, Canada; National Marine Fisheries Services, Woods Hole, Massachusetts, USA.

Transboundary Resources Assessment Committee (TRAC). 2018a. Eastern Georges Bank cod. TRAC Status Report 2018/01. 
National Oceanic and Atmospheric Administration, Silver Spring, Maryland, USA.

Transboundary Resources Assessment Committee (TRAC). 2018b. Eastern Georges Bank haddock. TRAC Status Report 2018/02. National Oceanic and Atmospheric Administration, Silver Spring, Maryland, USA.

Transboundary Resources Assessment Committee (TRAC). 2018c. Georges Bank yellowtail flounder. TRAC Status Report 2018/02. National Oceanic and Atmospheric Administration, Silver Spring, Maryland, USA.

United Nations. 1986. United Nations Convention on the Law of the Sea (UNCLOS) - Part V. United Nations, New York, New York, USA.

Van Der Voo, L. 2016. Conflict threatens to close Bering Sea halibut fishery. Anchorage Daily News, 28 September.

van Vuuren, D. P., J. Edmonds, M. Kainuma, K. Riahi, A. Thomson, K. Hibbard, G. C. Hurtt, T. Kram, V. Krey, J.-F. Lamarque, T. Masui, M. Meinshausen, N. Nakicenovic, S. J. Smith, and S. K. Rose. 2011. The representative concentration pathways: an overview. Climatic Change 109:5. https://doi. org/10.1007/s10584-011-0148-Z

Wickham, H. 2017. Package tidyverse; Easily install and Load the 'Tidyverse' $R$ (3.5.0)(1.2.1).

Xie, Y. 2020. A general-purpose package for dynamic report generation in $R$ [R package knitr version 1.27] R (3.2.3):GPL-2 | GPL-3.

Zeller, D., M. L. D. Palomares, A. Tavakolie, M. Ang, D. Belhabib, W. W. L. Cheung, V. W. Y. Lam, E. Sy, G. Tsui, K. Zylich, and D. Pauly. 2016. Still catching attention: Sea Around Us reconstructed global catch data, their spatial expression and public accessibility. Marine Policy 70:145-152. https://doi.org/10.1016/j.marpol.2016.04.046 
Appendix 1. Percentage change of MCP of transboundary fisheries of North America for endcentury (2081-2100) relative to 2005-2014 under high and low emission scenario.

A- High emission

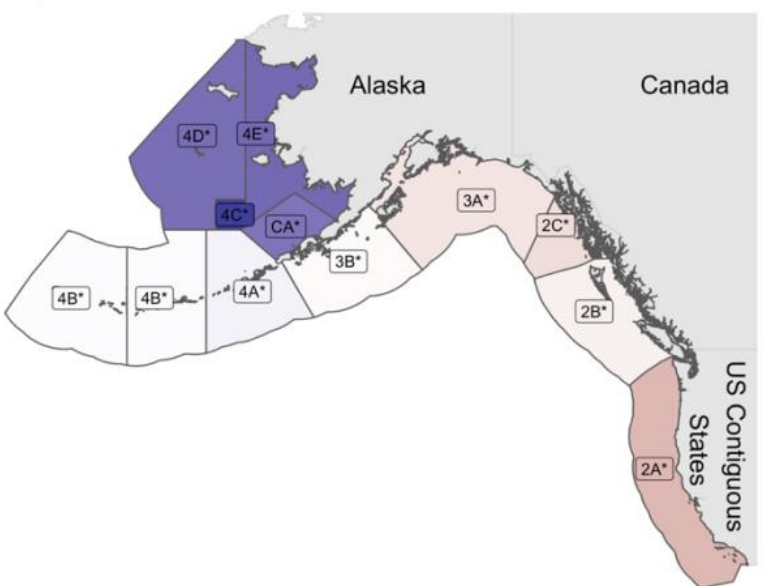

B - Low emission

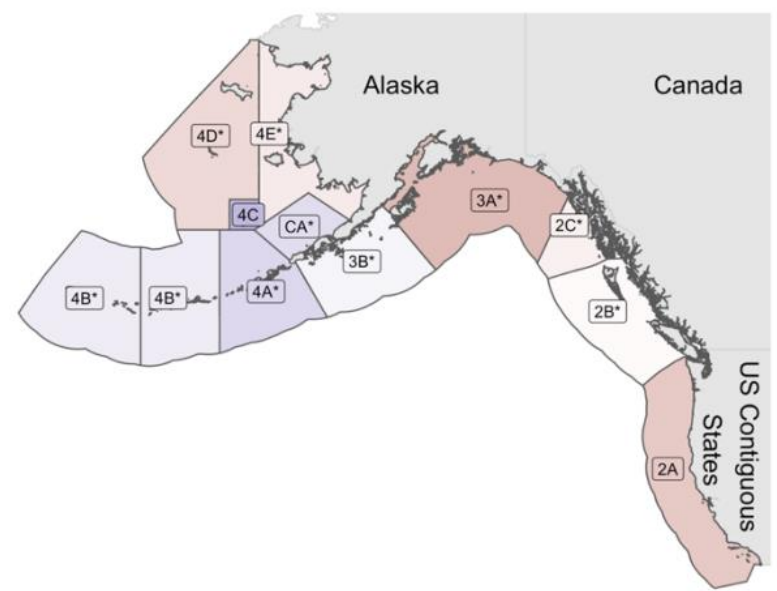

MCP Percentage Change (2081-2100)

$-50-45-40-35-30-25-20-15-10-5 \quad 0 \quad 5 \quad 10 \quad 152025 \quad 303540 \quad 45 \quad 50$

Fig. A1.1. Percentage change of MCP for species managed by the IPHC for end-century (20812100) relative to 2005-2014 under a (A) high emission scenario and (B) low emission scenario. Labels marked with "*" represent regions where models do not agree in direction of change. 

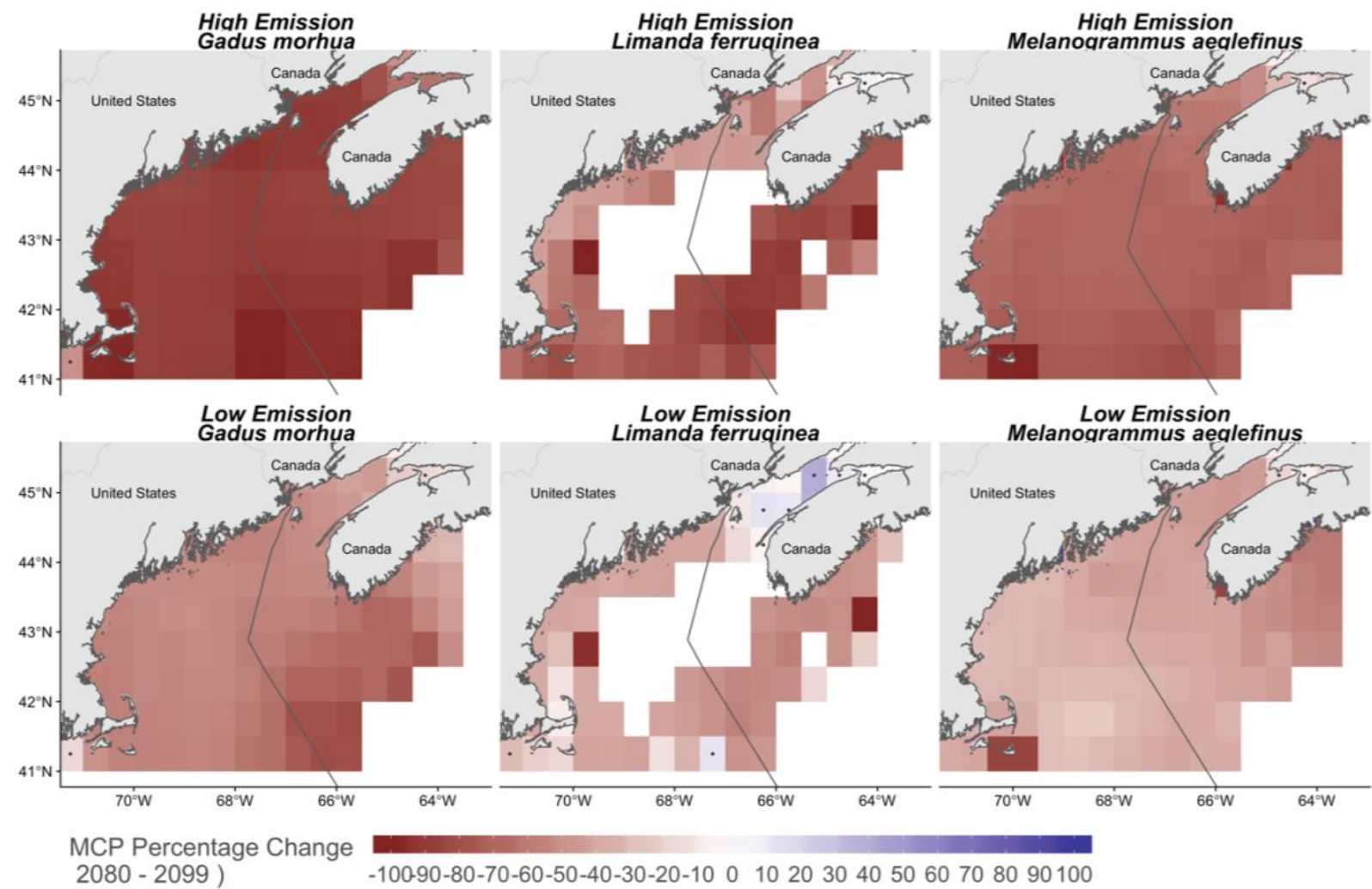

Fig. A1.2. Percentage change of MCP in the Gulf of Maine under (RCP 8.5) high emission scenario and (RCP 2.6) low emission for end-century (2080-2100) relative to present (20052014). Values represent the mean of 3 ESM. Points represent regions where ESMs do not agree in direction of change 
Appendix 2. Projected environmental variables under climate change.

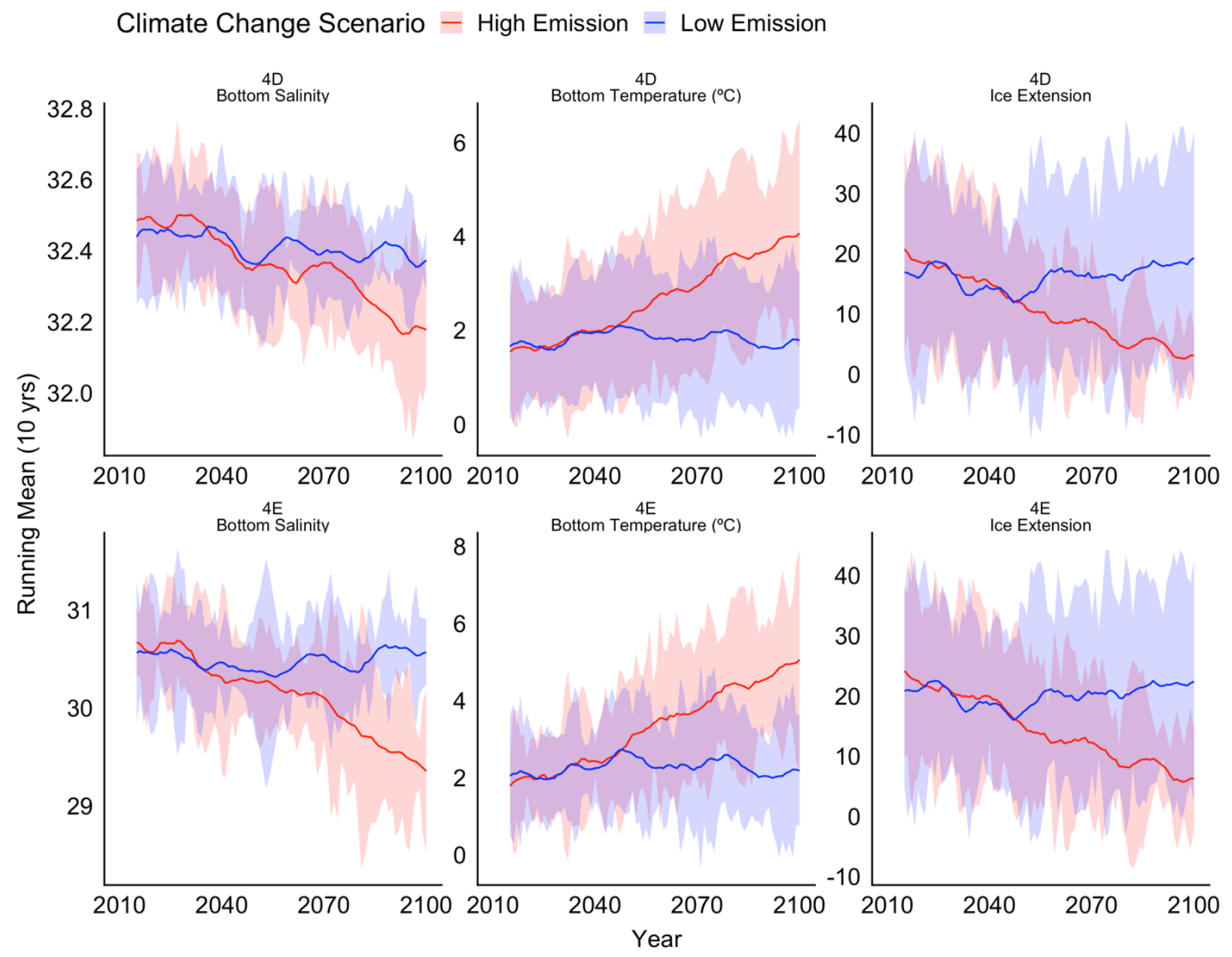

Fig A2.1. Projected environmental variables under climate change from 2010 to 2010 for Arctic regions of the IPHC (Top:4D, Bottom, 4E). The solid line represents the average of all three ESMs and the shaded area represents the model's uncertainty (s.d.). 

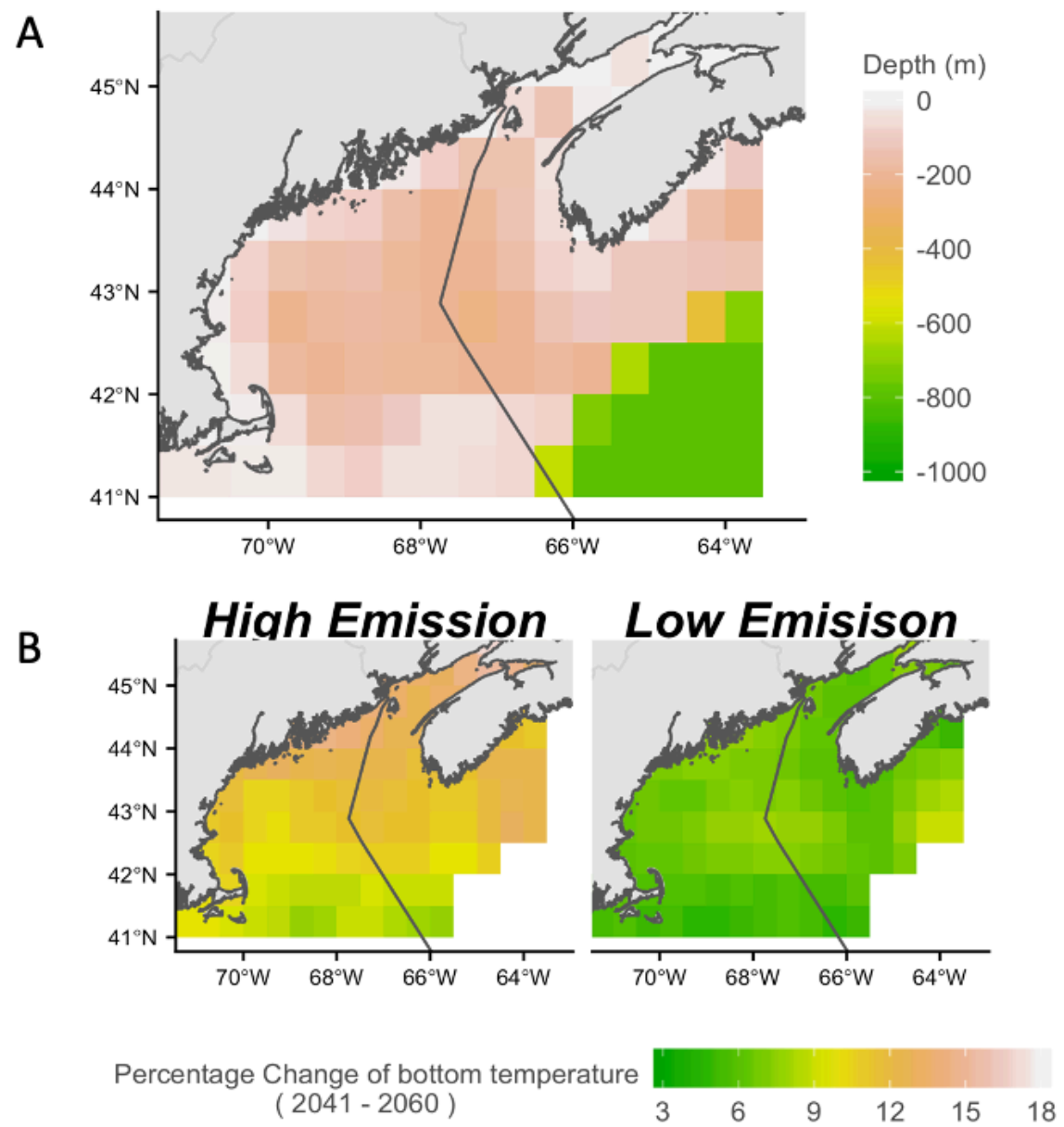

Fig. A2.2. Depth profile (A) and bottom water warming of the Gulf of Maine. Everything deeper than 1000 meters is colored in green. B) Percentage change of bottom temperature relative to the present showing more intense warming in northern regions, especially under a high emission climate change scenario. 

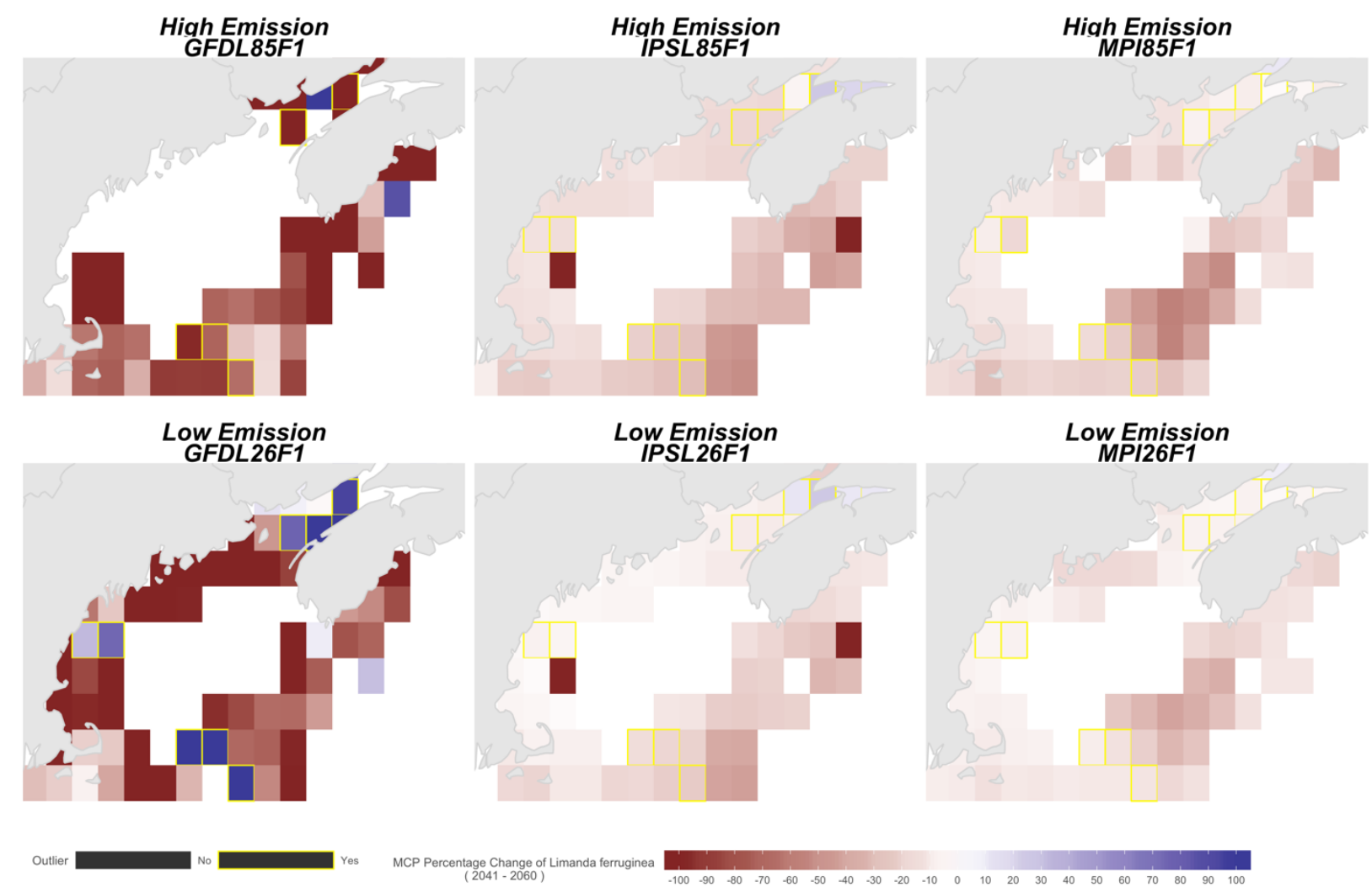

Fig A2.3. Changes in maximum catch potential of yellowtail flounder (Limanda ferruginea) within the study area by mid-century relative to present time. Results for the three global circulation models (GFDL, IPSL, MPIS) used in the current study and two climate change scenarios (Top: High emission - RCP 8.5, Bottom: Low Emission - RCP 2.6). Grid-cells marked in yellow represent discrete areas where average $\mathrm{MCP}$ is projected to increase by mid-century. 


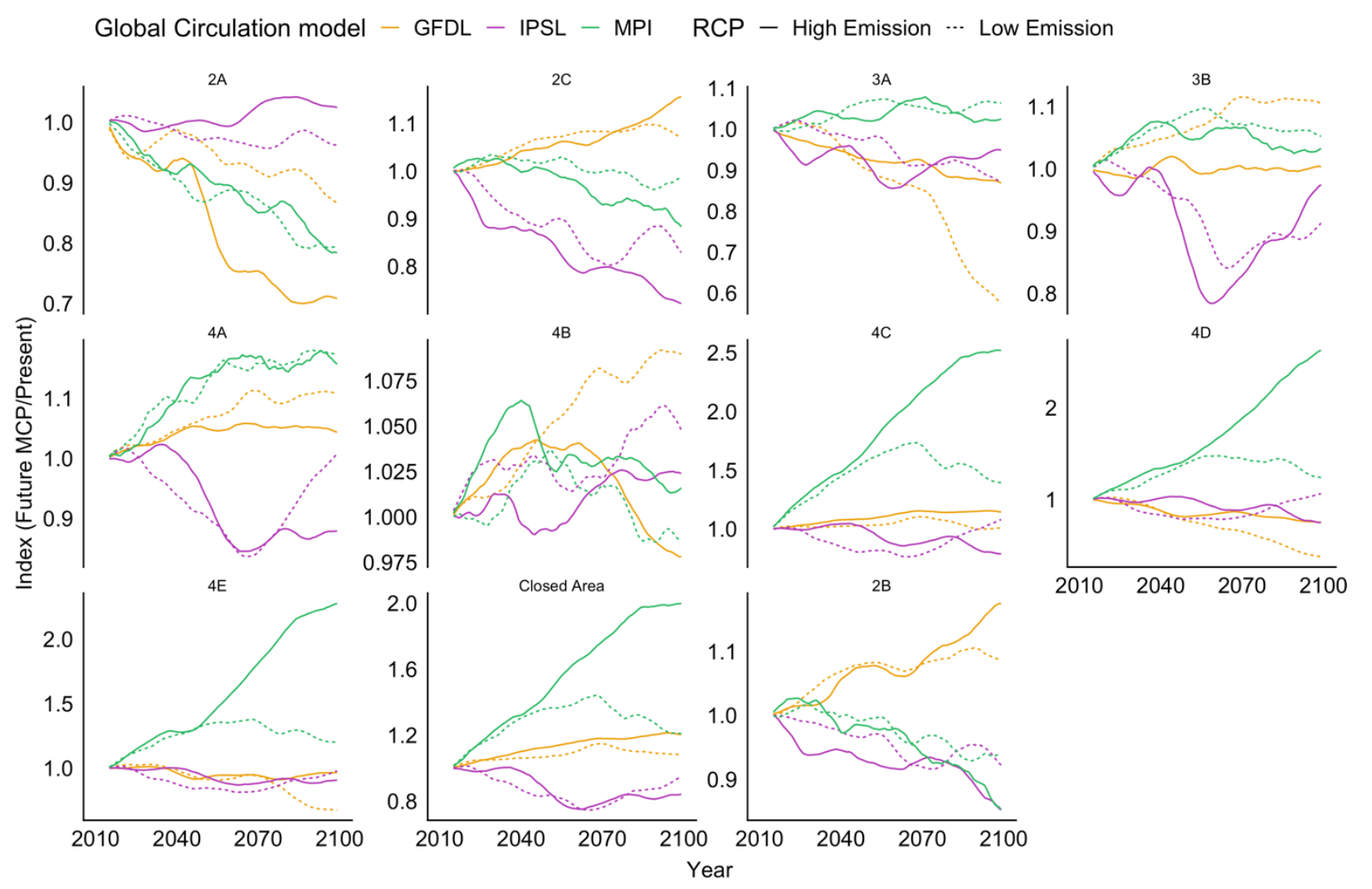

Fig A2.4. Projected max catch potential change relative to present (2005-2014) for each IPHC regulatory area. Colors represents the different ESM used in the study. Solid line represents a high emission scenario (RCP 8.5) and dashed line represents a low emission scenario (RCP 2.6) 